\title{
PERTANGGUNGJAWABAN DIREKTUR ATAS KEWENANGAN MEWAKILI PERSEROAN TERBATAS YANG TELAH HABIS MASA KEPENGURUSANNYA
}

\author{
Oleh : \\ Eduard Rudy Suharto \\ Email : eduardrudy@yahoo.com
}

\begin{abstract}
The Board of Directors is the only organ of the company that has power, authority and is fully responsible for managing the company solely for the interests of a company, in accordance with the company's goals and objectives, and has the power, authority and responsibility to represent the company both inside and outside the court with the provisions of the articles of association that have been made. Directors in the Company have a term of office as stated in the Deed of Establishment of a Limited Liability Company. If the term of office of the Board of Directors is exhausted, then it must be done by the GMS. If the Board of Directors does not hold a GMS, then the position of the Board of Directors is not valid before the Law and does not have an interest in representing the Company either inside or outside the Court.
\end{abstract}

Keywords : Directors, RUPS, Court 


\section{PENDAHULUAN}

\subsection{Latar Belakang Masalah}

Perseroan Terbatas (selanjutnya disebut dengan Perseroan) merupakan subjek hukum yang berbentuk badan hukum (recht person). Sama halnya seperti manusia (natuurlijk person) yang mempunyai subjek hukum, Perseroan pun mempunyai hak dan kewajiban. Perseroan dianggap cakap melakukan perbuatan hukum dengan subjek hukum yang lainnya namun hanya terbatas di dalam hukum harta kekayaan seperti membuat suatu perikatan, perjanjian sewa menyewa ataupun hutang piutang.

Perseroan lahir sebagai badan hukum tercipta melalui proses hukum. Itu sebabnya Perseroan disebut makhluk badan hukum yang berwujud artifisial (kumstmatig, artificial) yang dicipta negara melalui proses hukum yang berlaku. Keberadaan badan hukum dibuktikan berdasar Akta Pendirian yang di dalamnya tercantum Anggaran Dasar Perseroan. Perseroan sebagai makhluk artifisial disahkan oleh negara menjadi badan hukum memang tetap tidak bisa dilihat dan tidak dapat diraba. Akan tetapi, eksistensinya riil ada sebagai subjek hukum yang terpisah (separate) dan bebas (independent) dari pemiliknya atau pemegang saham maupun dari pengurus dalam hal ini Direksi Perseroan.
Perseroan melalui pengurus dapat melakukan suatu perbuatan hukum, seperti melakukan kegiatan Perseroan dalam hal membuat suatu perjanjian, transaksi, menjual asset dan menggugat atau digugat serta dapat bernafas layaknya manusia selama jangka waktu berdirinya yang ditetapkan dalam Anggaran Dasar belum berakhir. Perseroan mempunyai kedudukan hukum yang mandiri (persona standi judicio) walaupun tidak dapat bertindak tanpa organ-organnya. Secara umum eksistensi dan validitas sebuah Perseroan tidak terancam oleh kematian, kepailitan, penggantian atau pengunduran individu dari pemilik atau pemegang saham karena entitas yang terpisah antara pemilik dengan pemegang saham.

Pemegang saham tidak memiliki hak maupun kewajiban dari suatu perbuatan hukum. Setiap suatu keuntungan yang didapat oleh Perseroan dianggap sebagai keuntungan Perseroan, apabila Perseroan mengalami suatu kerugian maka hal tersebut menjadi beban dari Perseroan. Organ yang terdapat dalam Perseroan yaitu, RUPS, Direksi dan Komisaris. Direksi dan Komisaris menjalankan tugas dan kewenangannya sudah ditentukan dalam ADRT PT dan UU PT yang berlaku. Setiap Direksi dan Komisaris yang memimpin suatu Perseroan mempunyai masa tenggang waktu yang terdapat dalam Akta Pendirian Perseroan Terbatas. Direksi 
dalam menjalankan pengurusan Perseroan didasarkan pada tugas Kepercayaan (fiduciary duty). Sudah sepantasnya Direksi yang mempimpin suatu Perseroan mempunyai suatu itikad baik dalam menjalankan tugasnya karena harta yang dipercayakan kepadanya bukan digunakan untuk kepentingan pribadi Direksi tersebut tetapi kepentingan Perseroan.

\subsection{Perumusan Masalah}

Berdasarkan latar belakang yang telah dipaparkan diatas, maka permasalahan yang akan diteliti dapat dirumuskan sebagai berikut :

1. Apakah keputusan yang diambil oleh Direktur dalam mewakili Perseroan Terbatas sah demi hukum dengan lewatnya jangka waktu kepengurusan ?

2. Apa bentuk penyelesaian yang dapat diperoleh Pemegang Saham agar tindakan Direktur yang masa jabatan terakhir bisa menjadi sah ?

\section{METODE PENELITIAN}

Tulisan ini menggunakan metode penelitian hukum normatif, yaitu meneliti hukum dari perspektif internal dengan objek penelitiannya adalah norma hukum. Dengan kata lain penelitian hukum yang meletakkan hukum sebagai sebuah bangunan sistem norma. Sistem norma yang dimaksud adalah mengenai asas- asas, norma, kaidah dari peraturan perundangan, putusan pengadilan, perjanjian serta doktrin (ajaran). ${ }^{1}$

Pendekatan yang digunakan adalah pendekatan perundang-undangan dan pendekatan konseptual. Pendekatan perundang-undangan atau statute approach digunakan jika permasalahan penelitiannya mempermasalahkan konflik norma yang terjadi secara vertikal maupun horizontal. Dalam setiap penelitian atau survei terhadap sesuatu masalah dapatlah digunakan bermacam-macam cara atau metode seperti melakukan penelitian atau survei secara kepustakaan, melakukan interview dan sebagainya.

Pendekatan konseptual atau conceptual approach beranjak dari pandangan-pandangan dan doktrin-doktrin yang berkembang di dalam ilmu hukum, sehingga dapat menemukan ide-ide yang melahirkan pengertian-pengertian hukum, konsep-konsep hukum, dan asas-asas hukum yang relevan dengan isu yang dihadapi. $^{2}$

\footnotetext{
${ }^{1}$ I Made Pasek Diantha, 2016, Metodologi Penelitian Hukum Normatif dalam Justifikasi Teori Hukum (Jakarta: Prenada Media Grup).hlm12

2 Ibid, hlm. 159
} 
HASIL DAN PEMBAHASAN

\subsection{Keabsahan Keputusan Yang Diambi}

\section{Oleh Direktur Dalam Mewakili}

Perseroan Terbatas Dengan Lewatnya Jangka Waktu Kepengurusan

Direksi Perseroan adalah salah satu organ perseroan yang mempunyai tugas untuk melakukan pengurusan terhadap Perseroan, untuk kepentingan Perseroan sesuai dengan maksud dan tujuan Perseroan serta mewakii Perseroan baik di dalam maupun di luar Pengadilan sesuai dengan ketentuan Anggaran Dasar dan Anggaran Rumah Tangga Perseroan Terbatas (ADRT PT) tersebut. ${ }^{3}$ Suatu Direksi dalam menjalankan tugasnya memiliki dua fungsi yaitu : pengurusan dan perwakilan yang kesemuanya telah ditentukan dalam ADRT PT. Direksi adalah satu-satunya organ perseroan yang mempunyai kekuasaan, berwenang dan bertanggungjawab penuh atas pengurusan perseroan semata untuk kepentingan suatu perseroan, sesuai dengan maksud dan tujuan perseroan, serta mempunyai kekuasaan, berwenang dan bertanggung jawab penuh untuk mewakili perseroan baik di dalam maupun diluar pengadilan

3 Munir Fuady, 2010, Doktrin-Doktrin Modern Dalam Corporate Law Dan Eksistensinya Dalam Hukum Indonesia, Cetakan Kedua, Bandung : PT . Citra Aditya Bakti, hlm. 188 sesuai dengan ketentuan anggaran dasar yang telah dibuat. ${ }^{4}$

Oleh karena itu kapasitas mewakili Perseroan yang dimilikinya, adalah kuasa atau perwakilan karena undang-undang. Dengan demikian untuk bertindak mewakili Perseroan tidak memerlukan kuasa dari Perseroan. Sebab kuasa yang dimilikinya atas nama Perseroan adalah suatu kewenangan yang melekat secara inherent pada diri dan jabatan Direksi berdasarkan undang-undang.

Fungsi pengurusan (manajemen) yang dapat dilakukan oleh direksi saat melakukan tugas memimpim suatu perusahaan dan dalam hukum Jerman disebut dengan geschäftsführungsbefugnis. ${ }^{5}$ Pengurusan yang dilakukan oleh direksi dapat digolongkan menjadi 2 (dua) yaitu :

1. Beheren. Beheren adalah pengurusan dalam arti sempit yaitu perbuatan yang dilakukan sehari-hari (kontinyu). ${ }^{6}$ Pengurusan ini meliputi pengelolahan dan memimpin tugas sehari-hari yakni membimbing dan membina kegiatan dan aktivitas Perseroan kearah pencapaian maksud dan tujuan yang

Ibid, hlm. 25

Ibid, hlm. 30

Rudhi Prasetya, 2011, Perseroan Terbatas, Cetakan Pertama, Jakarta : Sinar Grafika, hlm. 20 
ditetapkan daam ADRT PT. ${ }^{7}$ Direksi sebagai pengurus adalah seorang pejabat Perseroan yang tidak mendapatkan hak dalam hal pembayaran prefensial (prefential payment) apabila perseroan terkena likuidasi.

2. Beschikking. Beschiking atau disebut juga daden van beschicking leigendom merupakan perbuatan kepemilikan dalam arti luas berupa perbuatan khusus atau istimewa. Setiap perbuatan pengurusan beschiking harus mendapatkan persetujuan oleh komisaris atau RUPS terlebih dahulu sesuai dengan ketentuan peraturan perundangundangan.

Pada dasarnya pertanggung-jawaban direksi adalah terbatas setelah dilakukan pendaftaran dan pengumuman Akta Pendirian yang telah disahkan Menteri Kehakiman. Akan tetapi, dalam keadaan tertentu tanggungjawab terbatas ini dapat menjadi tidak terbatas atau menjadi tanggungjawab pribadi ataupun tanggungjawab tanggung renteng sesama anggota Direksi. Hal ini terutama berhubungan dengan konsep piercing the corporate veil dan ultra vires. ${ }^{8}$

Suatu doktrin piercing the corporate veil dapat diterapkan yang menyebabkan

7 M.Yahya Harahap, 2011, Hukum Perseroan Terbatas, Cetakan Ketiga, Jakarta : Sinar Grafika, hlm..53

8 Trusto Subekti, Batasan Tanggung Jawab Direksi Atas Kerugian Perusahaan, Makalah, Fakultas Hukum Jendral Soedirman, hlm. 5 pihak direksi bertanggungjawab secara pribadi atas kegiatan yang dilakukan Perseroan Terbatas, dalam hal-hal sebagai berikut: Direksi tidak pernah melaksanakan fiduciary duty kepada Perseroan, dokumen perhitungan tahunan tidak benar. Direksi dikatakan bersalah dan menyebabkan suatu perusahaan menjadi pailit, Permodalan yang tidak layak sehingga perseroan beroperasi secara tidak layak.

Tanggungjawab pribadi direksi berdasarkan suatu prinsip ultra vires mengandung makna bahwa direksi tidak dapat melakukan kegiatan di luar kekuasaan direksi. Pengertian ultra vires mengandung arti bahwa perbuatan tertentu, yang apabila dilakukan manusia adalah sah, ternyata berada diluar kecakapan bertindak Perseroan sebagaimana diatur dalam Anggaran Dasar (AD) dan atau berada diluar lingkup maksud serta tujuannya. ${ }^{9}$

Adapun direksi dapat dikatakan telah melakukan perbuatan pelampauan wewenang apabila terpenuhi salah satu atau lebih kriteria sebagai berikut, apabila perbuatan tersebut dilarang oleh Anggaran Dasar, perbuatan tersebut bukanlah kegiatan usaha pokok Perseroan, dan perbuatan tersebut bukanlah suatu

9 Chatamartasjid Ais, Menyingkap Tabir Perseroan (Piercing The Corporate Veil) Kapita Selekta Hukum Perusahaan , Bandung ; Citra Aditya Bakti, 2000, hlm. 42 
kepentingan Perseroan. Semua ketentuan tentang ultra vires ini banyak negara diberlakukan dengan tegas, yakni transaksi yang demikian dianggap batal demi hukum, dan direktur yang meakukan tindakan tersebut akan bertanggungjawab secara pribadi. Tetapi lama kelamaan ketentuan tentang ultra vires menjadi semakin relaks, baik terus menambah panjangnya list dari perkecualian ataupun dengan memperluas penulisan ruang lingkup dari tujuan perseroan dalam anggaran dasar. ${ }^{10}$

Ketentuan Pasal 94 ayat (1) UU No 40 Tahun 2007 tentang Perseroan Terbatas menyatakan "Anggota Direksi diangkat oleh RUPS”. Bahwa kewenangan RUPS mengangkat anggota Direksi tidak dapat dilimpahkan kepada Organ Perseroan lainnya. Kewenangan tersebut mutlak berada di tangan RUPS. Tidak dapat dilimpahkan atau didelegasikan kepada Direksi maupun pihak lain seperti penguasa atau Pengadilan. Akan tetapi, untuk pengangkatan selanjutnya berpindah dari tangan Pendiri kepada RUPS. Ketentuan ini bersifat imperatif atau memaksa (dwingenrecht, mandatory law). Tidak bisa disampingi pengaturannya dalam AD Perseroan.

Masa jabatan atau masa kontrak jabatan Direktur boleh dikatakan ber-

\footnotetext{
10 Ibid, hlm. 11
}

variasi. Undang-undang sendiri tidak mengatur lamanya masa jabatan anggota Direksi. Biasanya hal itu diatur dalam AD Perseroan. Sekiranya AD tidak menetapkan lamanya masa jabatan, RUPS yang berwenang menentukan masa jabatan Direksi Perseroan. Mengenai masa jabatan anggta Direksi Pasal 94 ayat (3) UU No. 40 Tahun 2007 mengatakan "Anggota Direksi diangkat untuk jangka waktu tertentu dan dapat diangkat kembali". Selanjutnya penjelasan pasal ini mengatakan: (a). persyaratan pengangkatan anggota Direksi untuk "jangka waktu tertentu" dimaksudkan anggota Direksi yang telah berakhir masa jabatannya, tidak dengan sendirinya meneruskan jabatannya semula, (b). Tetapi harus dengan pengangkatan kembali berdasarkan keputusan RUPS.

Dalam penjelasan pasal tersebut dapat dikemukakan contoh. Misalnya masa jabatan anggota Direksi yang ditentukan dalam AD atau RUPS untuk jangka waktu 3 (tiga) atau 5 (lima) tahun sejak tanggal pengangkatan maka sejak berakhirnya jangka waktu tersebut, mantan anggota Direksi yang bersangkutan : (a). Tidak berhak lagi bertindak untuk dan atas nama Perseroan; (b). Agar dia dapat bertindak untuk dan atas nama Perseroan, harus diangkat kembali menjadi anggota Direksi oleh RUPS. 
Tanpa mengurangi ketentuan yang membolehkan $\mathrm{AD}$ mengatur tata cara pencalonan, penggantian dan pemberhentian anggota Direksi maka : (a). setiap pengangkatan dan penggantian anggota Direksi keputusan RUPS yang bersangkutan harus "menetapkan" saat mulai berlakunya pengangkatan, penggantian dan pemberhentian tersebut, (b). Apabila keputusan RUPS tidak menetapkan saat mulai berlakunya maka penggangkatan, penggantian dan pemberhentian anggota Direksi mulai berlaku sejak ditutupnya RUPS.

Pengangkatan, penggantian, dan pemberhentian anggta Direksi dapat dijelaskan oleh UU No. 40 Tahun 2007 tentang Perseroan Terbatas, tidak dikategorikan sebagai perubahan $\mathrm{AD}$ tertentu yang digariskan Pasal 21 ayat (2). Akan tetapi, menurut Penjelasan Pasal 29 ayat (3) huruf c, dikategori sebagai "perubahan data" Perseroan, penjelasannya tersebut berbunyi "Yang dimaksud dengan "perubahan data Perseroan" adalah antara lain data tentang pemindahan hak atas saham, penggantian anggota Direksi dan Dewan Komisaris, pembubaran Perseroan".

Direksi Perseroan mempunyai kewajiban yang ditunjukan kepada :

1. Kewajiban kepada Perusahaan. Direksi wajib menempatkan kepentingan perusahaan sebagai kepentingan yang tertinggi lebih tinggi dari pada kepentingan pribadi maupun kepentingan bentuk usaha yang dimilikinya semua tindakan yang dilakukannya harus diyakini bahwa hal tersebut dilakukannya atas nama perusahaan.

2. Kewajiban kepada pemegang saham direksi wajib menyediakan informasi yang cukup bagi pemegang saham atas jalannya perusahaan. Apabila terdapat pelanggaran hak pemegang saham, maka direksi dapat dimintai pertanggungjawaban secara pribadi.

3. Kewajiban kepada stakeholder. Stakeholder ialah pihak ketiga yang dapat berupa investor. Perusahaan yang sehat akan lebih menjamin perlindungan kepentingan bagi pihak ketiga.

Direksi memimpin suatu Perseroan mempunyai kewajiban antara lain :

a. Duty of care. Duty of care atau prudential duty ialah anggota direksi tidak boleh sembrono (carelessly) dan lalai (neglegence) melaksanakan pengurusan menurut hukum yang berpatokan pada standar kehati-hatian yang lazimnya digunakan oleh orang biasa. Direksi dalam hal ini diharapkan untuk berbuat secara hati-hati sehingga terhindar dari kelalaian yang merugian dari pihak lain. Direksi mempunyai kewajiban untuk memberi perhatian dan 
berusaha mengambi keputusan baik dan tepat.

b. Duty to disclosure. Disclosure memberikan kepastian atas akses informasi oleh semua pihak-pihak yang berkepentingan berdasarkan tujuan untuk mematuhi informasi memalui prosedur yang transparan dimana informasi tersebut mudah untuk didapatkan.

c. Duty of loyality. Makna dari duty of loyality adalah menduduki posisi sebagai anggota direksi, tidak menggunakan dana perseroan untuk dirinya atau untuk tujuan pribadinya dan secara loyal, wajib merahasiakan segala informasi.

d. Duty to minitor. Direksi dalam mengelola perusahaan harus menerapkan kontrol internal atas manajemen perusahaan.

Direksi merupakan organ yang sangat penting dalam Perseroan. Tanpa adanya Direksi maka Perseroan tidaklah jalan dan berfungsi selayaknya sebuah badan 74okum. Suatu Perseroan mempunyai ketergantungan yang sangat besar kepada Direksi. Apabila salah seorang Direksi lalai atau melanggar kewajiban pengurusan secara itikad baik dan penuh tanggung jawab sesuai dengan lingkup aspek-aspek itikad baik dan pertanggungjawaban atas pengurusan tersebut, maka anggota Direksi sama-sama ikut memikul tanggung jawab secara tanggung renteng terhadap kerugian yang dialami Perseroan. ${ }^{11}$

\subsection{Bentu k Penyelesaian Yang Dapat Diperoleh Pemegang Saham Agar Tindakan Direktur Yang Masa Jabatan Berakhir Menjadi Sah}

Bentuk suatu penyelesaian para pemegang saham terhadap tindakan Direksi yang telah habis masa jabatannya adalah melalui RUPS. RUPS (Rapat Umum Pemegang Saham) merupakan rapat yang dilakukan oleh para pemegang saham dalam kedudukan hukum mereka sebagai pemilik Perseroan. Setiap rapat maka harus jelas ditentukan tempat pelaksanaanya dan mata acara yang akan di rapatkan oleh pemegang saham lainnya.

Melalui RUPS sangatah jelas kedudukan Direksi Perseroan yang telah habis masa jabatan sesuai dengan $\mathrm{AD}$ dan masih menjabat kepemimpinan Perseroan maka dapat dikatakan tidaklah sah. Begitu pula mengenai laporan keuangan Perseroan, jika Direksi mempunyai suatu itikad buruk, lalai dalam menjalankan Perseroan dan mengambil keuntungan Perseroan untuk kepentingan pribadi maka Direksi tersebut sangatlah tidak cocok untuk memimpin sebuah Perseroan dan dapat diganti melalui RUPS.

11 M. Yahya Harahap, Op.Cit, hlm. 384 
RUPS dapat diadakan di tempat kedudukan Perseroan. Ketentuan ini merupakan lexgeneralis (general rule) yang berlaku umum bagi semua Perseroan termasuk Perseroan Terbuka. Menurut Pasal 76 ayat (4) membuka kemungkinan mengadakan RUPS di tempat mana sajapun. Namun agar kebolehan mengadakan RUPS dimanapun, harus terpenuhi syarat-syarat berikut ini :

a. RUPS dihadiri dan / atau diwakili oleh "semua" pemegang saham;

b. Semua pemegang saham menyetujui;

c. Agenda RUPS yang disetujui harus tertentu;

d. Tempat RUPS diadakan harus terletak di Wilayah Negara Republik Indonesia;

Syarat-syarat tersebut harus di penuhi, agar RUPS dapat diadakan di manapun diluar tempat kedudukan Perseroan maupun diluar kegiatan usaha yang utama. Selanjutnya RUPS yang diadakan di mana saja pun sesuai dengan syarat-syarat dikemukakan tersebut, hanya dapat mengambil keputusan tersebut apabila disetujui dengan suara bulat. ${ }^{12}$

Bertitik tolak dari ketentuan dimaksud, setiap Perseroan harus mengadakan suatu RUPS tahunan untuk setiap tahun kalender. Ketentuan ini tidak hanya terjadi di Indonesia, tetapi juga

12 Munir Fuady, Op.Cit, hlm. 35 diterapkan oleh semua negara. Direksi harus mengajukan semua dokumen dari laporan tahunan perseroan yang nantinya akan digunakan dalam mata acara RUPS antara lain : laporan keuangan, laporan mengenai kegiatan Perseroan, laporan pelaksanaan TJSL, rincian masalah yang timbu selama tahun buku yang mempengaruhi kegiatan Perseroan, dan laporan tugas pengawasan yang dilaksanakan Dewan Komisaris. ${ }^{13}$ Direksi juga berhak menyelenggarakan RUPS lainnya dalam praktiknya dapat dikenal dengan RUPS LB dengan tujuan maka : dapat diadakan setiap waktu dan digantungkan berdasar kebutuhan untuk kepentingan Perseroan.

Pada dasarnya yang berhak menyelenggarakan RUPS sepenuhnya adalah Direksi. Namun yang dapat atau berhak meminta kepada Direksi supaya diadakan dan diselenggarakan RUPS tahunan atau RUPSLB adalah :

1. 1 (satu) orang atau lebih pemegang saham yang bersama-sama mewakili 1/10 (satu persepuluh) atau lebih jumlah seluruh saham dengan hak suara, kecuali AD menentukan suatu jumlah yang kecil, atau ;

2. Dewan Komisaris

3. Jika berpatokan pada ketentuan Pasal 79 ayat (2) huruf a, yang berhak meminta

13 Ibid, hlm. 315 
adalah pemegang saham yang mewakili paling sedikit $1 / 10$ (satu persepuluh) jumlah seluruh saham dengan hak suara.

Agar permintaan pemegang saham atas penyelenggaraan RUPS memenuhi persyaratan terdiri atas : (a) bentuk permintaan diajukan dengan Surat Tercatat, (b) diajukan kepada Direksi, dan tembusannya disampaikan kepada Dewan Komisaris beserta alasannya. Menurut Penjelasan Pasal 79 ayat (3), alasan yang menjadi dasar permintaan diadakan RUPS, antara lain :

a. Karena Direksi tidak mengadakan RUPS tahunan sesuai dengan batas waktu yang ditentukan Pasal 78 ayat (2), yang mewajibkan RUPS tahunan diadakan dalam jangka waktu paling lambat 6 (enam) bulan setelah tahun buku terakhir, atau;

b. Masa jabatan anggota Direksi dan/atau anggota Dewan Komisaris akan berakhir ;

Apabila ada permintaan dari pemegang saham atau dari Dewan Komisaris yang memenuhi syarat kepada Direksi agar diadakan RUPS maka menurut Pasal 79 ayat (5) "Direksi wajib melakukan panggilan RUPS dan panggian RUPS harus dilakukan Direksi, paling lambat 15 (lima belas) hari terhitung sejak tanggal permintaan penyelenggaraan RUPS diterima Direksi”. RUPS yang diselenggarakan Direksi berdasar panggilan RUPS atas permintaan, pada prinsipnya hanya membicarakan masalah yang berkaitan dengan alasan yang dikemukakan pada surat permintaan.

Direksi tidak melakukan pemanggian RUPS dalam jangka waktu 15 (lima belas) hari dari tanggal permintaan di terimanya. Kalau permintaan kembali penyelenggaraan RUPS oleh pemegang saham kepada Dewan Komisaris. Dewan Komisaris wajib melakukan pemanggilan RUPS paling lambat 15 (lima belas) hari sejak tanggal permintaan penyelenggaraan RUPS diterima. Selanjutnya, RUPS yang diselenggarakan oleh Dewan Komisaris berdasarkan panggilan RUPS atas permintaan pemegang saham, hanya membicarakan masalah yang berkaitan dengan alasan yang dikemukakan dalam surat permintaan.

Persyaratan kuorum dan pengambilan keputusan RUPS menurut Pasal 77 ayat (2), tunduk kepada persyaratan yang ditentukan dalam undang-undang ini atau diatur di dalam Anggaran Dasar Perseroan. Jika berpedoman kepada ketentuan Undang-Undang No. 40 Tahun 2007, telah diklasifikasi syarat kuantitas kuorum kehadiran dan pengambilan keputusan bagi setiap agenda atau mata acara RUPS seperti berikut ini :

1. Syarat kuorum kehadiran dan pengambilan keputusan RUPS 
mengenai mata acara biasa, diatur pada

Pasal 86:

a. Kuorum kehadirannya $1 / 2$ (satu per dua) bagian dari jumlah seluruh saham dengan hak suara, hadir atau di wakili;

b. Selanjutnya menurut Pasal 87 ayat (2), keputusan sah, jika disetujui lebih dari $1 / 2$ (satu per dua) bagian dari jumlah suara yang dikeluarkan;

2. Syarat kuorum dan pengambilan keputusan RUPS untuk jenis mata acara atau agenda perubahan Anggaran Dasar diatur pada Pasal 88, dengan ketentuan sebagai berikut :

a. Syarat kuorum kehadiran, paling sedikit 2/3 (dua pertiga) bagian dari jumlah seluruh saham dengan hak suara, hadir atau diwakili, dan ;

b. Keputusan sah, jika disetujui paling sedikit 2/3 (dua pertiga) bagian dari jumlah suara yang dikeluarkan ;

3. Syarat kuorum kehadiran dan pengambilan keputusan RUPS mengenai mata acara Penggabungan, Peleburan, Pengambilalihan atau Pemisahan, pengajuan permohonan agar Perseroan dinyatakan Pailit, perpanjangan jangka waktu berdirinya dan pembubaran Perseroan, merujuk Pasal 89 dengan ketentuan sebagai berikut :

a. Syarat kuorum kehadiran, paling sedikit 3/4 (tiga perempat) bagian dari jumlah seluruh saham dengan hak suara, hadir atau diwakili,

b. Keputusan sah, apabila disetujui paling sedikit $3 / 4$ (tiga perempat) bagian dari jumah suara yang dikeluarkan;

Permintaan Penyelenggaraan RUPS kepada Ketua Pengadilan Negeri diatur dalam Pasal 80 Undang-Undang No. 40 Tahun 2007 yang memberik hak kepada pemegang saham mengajukan permohonan penyelenggaraan RUPS kepada Ketua Pengadilan Negeri setempat. Berdasar Pasal 80 ayat (1), hak pemegang saham terbuka mengajukan "permohonan" kepada Ketua Pengadian Negeri meminta penyelenggaraan RUPS :

a) Apabila Direksi atau Dewan Komisaris tidak melakukan pemanggilan RUPS dalam jangka waktu 15 (lima belas) hari dari tanggal penerimaan surat ;

b) Bentuknya adalah permohonan yang dituangkan dalam Surat Permohonan (verzoekschriff, petition), bukan gugatan (vordering, claim) ;

c) Diajukan kepada Ketua Pengadilan Negeri sesuai dengan asas actor sequitor forum rei, yakni yang daerah hukumnya meliputi tempat kedudukan Perseroan;

d) Isi permintaan permohonan, agar Ketua Pengadilan Negeri menetapkan pemberi izin kepada Pemohon melakukan sendiri pemanggilan RUPS. 
Memperhatikan ketentuan diatas, hak pemegang saham mengajukan permohonan meminta penyelenggaraan RUPS, tidak langsung demi hukum terbuka. Harus ditempuh lebih dahulu permintaan kepada Direksi atau Dewan Komisaris. Apabila mereka tidak memenuhi permintaan paling lambat dalam jangka waktu 15 (llima belas) hari dari tanggal surat permintaaan diterima, baru terbuka hak pemegang saham mengajukan permohonan kepada Ketua Pengadilan Negeri.

\section{PENUTUP}

\section{Kesimpulan}

1. Mengenai masa jabatan anggta Direksi Pasal 94 ayat (3) UU No. 40 Tahun 2007 mengatakan "Anggota Direksi diangkat untuk jangka waktu tertentu dan dapat diangkat kembali”. Selanjutnya penjelasan pasal ini mengatakan : (a). persyaratan pengangkatan anggota Direksi untuk "jangka waktu tertentu” dimaksudkan anggota Direksi yang telah berakhir masa jabatannya, tidak dengan sendirinya meneruskan jabatannya semula, (b). Tetapi harus dengan pengangkatan kembali berdasarkan keputusan RUPS. Dalam penjelasan pasal tersebut dapat dikemukakan contoh. Misalnya masa jabatan anggota Direksi yang ditentukan dalam AD atau RUPS untuk jangka waktu 3 (tiga) atau 5 (lima) tahun sejak tanggal pengangkatan maka sejak berakhirnya jangka waktu tersebut, mantan anggota Direksi yang bersangkutan : (a). Tidak berhak lagi bertindak untuk dan atas nama Perseroan; (b). Agar dia dapat bertindak untuk dan atas nama Perseroan, harus diangkat kembali menjadi anggota Direksi oleh RUPS.

2. Melalui RUPS sangatah jelas kedudukan Direksi Perseroan yang telah habis masa jabatan sesuai dengan $\mathrm{AD}$ dan masih menjabat kepemimpinan Perseroan maka dapat dikatakan tidaklah sah. Begitu pula mengenai laporan keuangan Perseroan, jika Direksi mempunyai suatu itikad buruk, lalai dalam menjalankan Perseroan dan mengambil keuntungan Perseroan untuk kepentingan pribadi maka Direksi tersebut sangatlah tidak cocok untuk memimpin sebuah Perseroan dan dapat diganti melalui RUPS. RUPS dapat diadakan di tempat kedudukan Perseroan. Ketentuan ini merupakan lex generalis (general rule) yang berlaku umum bagi semua Perseroan termasuk Perseroan Terbuka. Menurut Pasal 76 ayat (4) membuka kemungkinan mengadakan RUPS di tempat mana sajapun. 


\section{Saran}

Apabila Direksi ingin tetap menjabat sebagai Direktur di dalam Perseroan ketika telah masa jabatan habis, maka haruslah melalui RUPS agar semua pemegang saham setuju terhadap perpanjangan masa jabatan yang telah habis Direksi tersebut dalam memimpin sebuah Perseroan Terbatas. Jika tidak dilakukannya RUPS maka keputusan ataupun perbuatan hukum yang dilakukan oleh seorang Direksi tersebut tidak sah dan tidak mempunyai legal standing sesuai dengan peraturan perundang-undangan yang berlaku di negara Indonesia.

\section{DAFTAR PUSTAKA}

Chatamartasjid Ais, Menyingkap Tabir Perseroan (Piercing The Corporate Veil) Kapita Selekta Hukum Perusahaan , Bandung ; Citra Aditya Bakti, 2000.

I made Pasek Diantha, 2016, Metodologi Penelitian Hukum Normatif dalam Justifikasi Teori Hukum (Jakarta: Prenada Media Grup).

Munir Fuady, 2010, Doktrin-Doktrin Modern Dalam Corporate Law Dan Eksistensinya Dalam Hukum Indonesia, Cetakan Kedua, Bandung : PT . Citra Aditya Bakti.

M.Yahya Harahap, 2011, Hukum Perseroan Terbatas, Cetakan Ketiga, Jakarta : Sinar Grafika.

Rudhi Prasetya, 2011, Perseroan Terbatas, Cetakan Pertama, Jakarta : Sinar Grafika.

Trusto Subekti, Batasan Tanggung Jawab Direksi Atas Kerugian Perusahaan, Makalah, Fakultas Hukum Jendral Soedirman. 
Peraturan Perundang-undangan :

- Undang- Undang Nomor 40 Tahun 2007 tentang Perseroan Terbatas.

\section{BIODATA SINGKAT PENULIS}

Eduard Rudy Suharto berprofesi sebagai Advokat/Konsultan Hukum. Menyelesaikan pendidikan Sarjana Hukum pada Fakultas Hukum, Universitas Tujuh Belas Agustus, Surabaya tahun 1993. Pada saat ini sedang menempuh pendidikan Magister Hukum pada Program Pasca Sarjana Fakultas Hukum, Universitas Narotama, Surabaya. 